\title{
Characteristics of Carcass and Meat Quality for Landrace, Yorkshire, Duroc and their Crossbreeds
}

\author{
J. H. Kim, B. Y. Park, Y. M. Yoo, S. H. Cho, I. H. Hwang, P. N. Seong, \\ K. H. Hah and J. M. Lee \\ National Livestock Research Institute
랜드레이스, 요크셔, 듀록 및 교잡종에 대한 도체 및 육질특성 김진형 · 박범영 · 유영모 · 조수현 · 황인호 · 성필남 · 하경희 · 이종문
농촌진흥청 축산연구소

\begin{abstract}
적 요
순종 돼지와 교잡종 돼지의 도체 및 육질특성을 구명하기 위하여 랜드레이스 81 두, 요크셔 123 두 및 종료 웅돈인 듀록 100 두와 랜드레이스 $\times$ 요크셔의 교배로 생산된 F1 모돈 62두, 그리고 F1 모돈에 듀록 웅돈을 교 배시켜 생산한 삼원교잡종 120 두를 도축한 후 도체 특성을 측정하고, 좌도체 등심을 채취하여 육질 특성을 조 사하였다. 생체중은 삼원 교잡종(LYD)이 가장 컸으며, 렌드레이스(LL)종이 가장 적었다. 도체율은 삼원교잡종 이 가장 높았으며, 거래정육율은 요크셔종과 F1종이 가장 높았다. 등지방층 두께는 삼원교잡종이 가장 두꺼웠 고, 렌드레이스종이 가장 얇았으며, 도체장은 $\mathrm{F} 1$ 종이 가장 길었고, 듀록종이 가장 짧았다. 일반조성분 중 조단 백질 함량은 F1종이 다른 순종 및 삼원 교잡종 보다 높은 반면 듀록종이 가장 낮았다( $<<0.05)$. 조지방은 삼원 교잡종과 듀록종이 다른 순종 및 $\mathrm{F} 1$ 종 보다 높은 함량을 보였다 $(\mathrm{p}<0.05)$. 사후 1 시간 $\mathrm{pH}$ 는 삼원 교잡종이 다 른 순종 및 $\mathrm{F} 1$ 종에 비하여 높은 반면 사후 24시간 $\mathrm{pH}$ 에서는 듀록종이 $\mathrm{F} 1$ 종 및 삼원 교잡종 보다 높게 나타 났다(p<0.05). 물리적 특성 중 전단력가는 삼원 교잡종이 랜드레이스에 비하여 연한 것으로 나타났고( $<0.05)$, 보수성은 삼원 교잡종이 다른 순종 및 $\mathrm{F} 1$ 종에 비하여 높게 나타났다 $(\mathrm{p}<0.05)$. 가열감량은 $\mathrm{F} 1$ 종이 가장 높았고, 삼원 교잡종이 가장 낮았으며(p<0.05), Purge loss는 듀록종이 원종, F1종 및 삼원 교잡종 보다 낮은 반면에 랜 드레이스종이 가장 높았다 $(\mathrm{p}<0.05)$. 육색 중 $\mathrm{L}$ 값은 랜드레이스종이 다른 순종, $\mathrm{F} 1$ 종 및 삼원 교잡종 보다 높았 고, a값은 F1종과 랜드레이스종이 다른 순종 및 삼원 교잡종에 비하여 높았으며, b값은 랜드레이스종이 가장 높은 반면, 듀록종이 가장 낮았다. 관능평가 중 다즙성과 연도에서는 듀록종과 삼원 교잡종이 원종 및 $\mathrm{F} 1$ 종 보다 높았고( $\mathrm{p}<0.05)$, 향미는 삼원 교잡종이 높은 평가를 받았다. 이상의 결과에서 듀록종과 삼원 교잡종은 다 른 순종들과 F1종에 비하여 육질은 좋았으나 도체특성이 떨어지는 것으로 나타나 삼원 교잡종 생산에 있어 육질과 도체특성을 동시에 향상시킬 수 있는 최종 웅돈 품종을 찾아내기 위한 연구가 필요한 것으로 보인다.
\end{abstract}

(Key words: Crossbred, Carcass characteristics, Meat quality, Pigs)

\section{I . INTRODUCTION}

Pork quality is a function of multi-factors including breed, feeding scheme, and pre- and post-slaughter managements. However, breed has been attributed as to the most significant single factor influencing sensory properties (Monin, 1983), and was also related to intramuscular fat, water-binding capacity, color and tenderness (Sellier and Monin, 1994).
It has been well documented that intramuscular fat positively influence juiciness, tenderness and flavour (Wood et al. 2003), as well as reduces shearing force required for mastication (EssenGustavsson et al., 1994). A number of sensory studies indicated that the effect of intramuscular fat on sensory attributes became detectable when pork chop contained greater than $2 \%$ of the fat (Bejerholm and Barton-Gade, 1986); while 2.5

\footnotetext{
Corresponding author : Dr. JinHyoung Kim, National Livestock Research Institute, RDA, 564 Omokchun-dong, Suwon 441-350, Tel : 82-31-290-1699, Fax : 82-31-290-1697, E-mail:jhkim702@rda.go.kr.
} 
3\% was necessary for the acceptable level of tenderness (Devol et al., 1988).

Duroc breed is known for higher intramuscular fat than other breeds (Barton-Gade, 1988), and for more a rapid growth rate than the Hampshire and the Yorkshire breed (Wilson and Johnson, 1981). For the reason, in pork industry of South Korea, approximately $60 \%$ of the 15.3 million pigs annually slaughtered are composed of threeway crossbreds, with Duroc boar as terminal sire. However, there is no accessible information about productivity and meat quality traits of commercially used pure breeds and their crossbreds. Thus, the current study was designed to evaluate carcass traits and meat quality of Landrace, Yorkshire, Duroc, Landrace $\times$ Yorkshire (LY) and Landrace $\times$ Yorkshire $\times$ Duroc $($ LYD) crossbred pigs

\section{П. MATERIALS \& METHODS}

\section{Animals and experimental design}

A total of 486 pigs used in this experiment comprised 81 Landrace (38 female, 27 male, 16 castration), 123 Yorkshire (60 female, 45 male, 18 castration), 100 Duroc (55 female, 45 male), 62 Landrace sires $\times$ Yorkshire dams crossbred (LY; 28 female, 22 male, 12 castration) and 120 LandraceYorkshire dams $\times$ Duroc sires crossbred (LYD; 54 female, 66 castration). Over 2 year of experimental period, pigs produced by the Darby Genetics Inc. under the same environmental condition with an identical diet. Landrace, Yorkshire and LY were produced and slaughtered in the spring and fall of the same year and Duroc and LYD were produced and slaughtered in the spring and fall of the same year. At approximately 96 108 kg live weight (approximately 180 days), $10 \sim 15$ pigs were conventionally transported to the National Livestock Research Institute abattoir with minimum transit stress. After a $12 \mathrm{~h}$ resting, pigs were conventionally slaughtered over 25 consecutive days. Carcasses were chilled at $4^{\circ} \mathrm{C}$ for $24 \mathrm{~h}$. The following day the left sides were ribbed at the 11 th/12 ribs, and back-fat thickness and loin muscle area were determined according to the method described by APGS (1995). Carcass length, carcass percentage and retail lean meat percentage were measured for the same side (Kim et al., 2002). pH was measured using a portable needle-tipped combination electrode (NWKbinar pH-K21, Germany) in the center of the muscle between the $3^{\text {rd }}$ and $4^{\text {th }}$ lumbar vertebrae at approximately 1 and $24 \mathrm{~h}$ postmortem.

\section{Meat quality measurements}

The following day after slaughter, $M$. longissimus dorsi (LD, from the $6^{\text {th }}$ to $13^{\text {th }}$ vertebrae thoracicae) was excised and taken to the meat science laboratory for determining moisture, protein, intramuscular fat, ash, WB shear force, Waterholding capacity, cooking loss, purge loss, meat color, and sensory characteristics. Percentage moisture, crude protein, intramuscular fat and ash were determined using the procedure of AOAC (1990). WB-Shear force was measured on cooked meat which was heated without cover in boiling water until an internal temperature of $75^{\circ} \mathrm{C}$. Three cores (Ø $13 \mathrm{~mm}$ ) cut along the fibre axis were taken from each sample and an average of 9 measurements was used for the final measurement (Park et al., 1999). Water-holding capacity was determined according to the filter paper method described by Grau and Hamm (1952, 1956) with slight modifications. Briefly, 0.5g of muscle tissue was placed on glass, and filter paper was pressed against the meat sample at $35 \sim 50 \mathrm{~kg} / \mathrm{cm}^{2}$ for 2 min. Water-holding capacity was calculated by using a planimeter. Percentage of cooking loss was calculated from weight loss during cooking for the WB-shear force measurement (sample weight, approximately 200 g) (Park et al., 1999). Purge loss was determined by weighing the muscle portions before vacuum-packaging and after 1 days at $4^{\circ} \mathrm{C}$ to calculate percentage weight losses. Meat color determined by a Minolta Chromameter (CR300, Minolta, Japan) on freshly cut surface after a 30 -min blooming at $4^{\circ} \mathrm{C}$. Sensory charac- 
teristics determined by 10 semi-trained panelists who were randomly selected from a total of 15 recruits. The panelists were asked to evaluate tenderness, flavor intensity and juiciness by a six-point assessment scheme (Park et al., 1999).

\section{Statistic analysis}

Differences between experimental groups for comparison of carcass and meat quality were tested using the General Linear Models (GLM) procedure of SAS (1998). Means were separated by Duncan's test $(\mathrm{p}<0.05)$.

\section{RESEULTS \& DISCUSSION}

\section{Effect of breed on carcass traits}

Table 1 presents carcass traits and percentage of retail lean meat. The results showed that carcass percent of LYD pigs had the highest dressing percentage with significantly $(\mathrm{p}<0.05)$ thicker back-fat, while Yorkshire and LY pigs showed significantly $(\mathrm{p}<0.05)$ higher retail lean meat percentages than other breeds. LY had the longest carcass length $(\mathrm{P}<0.05)$ among other breeds, whereby Duroc pigs were shortest. Loin eye area in the Yorkshire and LY pigs had significantly $(p<0.05)$ larger than other breed with the smallest for Duroc pigs. Differences between breed of dam and breed of sire effects for backfat and loin eye area suggested that maternal effects are important for these traits (Wilken et al., 1992). Sigvardsson (1983) found that Duroc-sired pigs had a higher lean weight than Swedish Landracesired pigs. Lo et al. (1992) reported that Durocsired pigs had less backfat thickness and larger loin eye area than Landrace-sired pigs. On the other hand, $\mathrm{pH}$ at $1 \mathrm{~h}$ postmortem of LYD pigs was higher than other breeds, but the Yorkshire pigs had the highest $\mathrm{pH}$ at 24 hour postmortem $(\mathrm{p}<0.05)$. Both Goodwin (1995) and Steindel and Kaczmarek (1980) observed breed differences in ultimate $\mathrm{pH}$. However, other studies (Enfalt et al. 1997; Essen-Gustavsson and Fjelkner-Modiz, 1985; Lo et al., 1992) failed to demonstrate breed differences in ultimate $\mathrm{pH}$. In the latter study, Durocs did not differ from Landrace in ultimate $\mathrm{pH}$.

In the chemical composition (table 1), less moisture content was found in LYD pigs compared with the other breeds, while protein content for LY pigs was higher than that for other breeds $(\mathrm{p}<0.05)$. An early study (Martel et al., 1988) showed that dry matter percentage was

Table 1. Mean and standard deviation for carcass quality from Landrace, Yorkshire, Duroc, LY and LYD crossbred pigs

\begin{tabular}{lrrrrr}
\hline Item & \multicolumn{1}{c}{ Landrace } & \multicolumn{1}{c}{ Yorkshire } & \multicolumn{1}{c}{ Duroc } & \multicolumn{1}{c}{ LY $^{\natural}$} & \multicolumn{1}{c}{ LYD } \\
\hline \hline Live weight (kg) & $97.71^{\mathrm{c}} \pm 0.85$ & $104.75^{\mathrm{a}} \pm 1.29$ & $100.73^{\mathrm{b}} \pm 1.12$ & $106.71^{\mathrm{a}} \pm 1.28$ & $107.19^{\mathrm{a}} \pm 0.80$ \\
Carcass percentage (\%) & $73.41^{\mathrm{bc}} \pm 0.18$ & $73.87^{\mathrm{b}} \pm 0.20$ & $73.18^{\mathrm{c}} \pm 0.24$ & $73.90^{\mathrm{b}} \pm 0.22$ & $74.77^{\mathrm{a}} \pm 0.11$ \\
Retail lean meat (\%) & $50.29^{\mathrm{b}} \pm 0.20$ & $52.13^{\mathrm{a}} \pm 0.26$ & $47.79^{\mathrm{d}} \pm 0.16$ & $51.94^{\mathrm{a}} \pm 0.27$ & $48.63^{\mathrm{c}} \pm 0.19$ \\
Backfat thickness (cm) & $1.82^{\mathrm{d}} \pm 0.05$ & $1.97^{\mathrm{cd}} \pm 0.05$ & $2.30^{\mathrm{b}} \pm 0.07$ & $2.00^{\mathrm{c}} \pm 0.05$ & $2.81^{\mathrm{a}} \pm 0.05$ \\
Carcass length (cm) & $80.84^{\mathrm{b}} \pm 0.29$ & $80.09^{\mathrm{b}} \pm 0.33$ & $76.14^{\mathrm{d}} \pm 0.30$ & $82.56^{\mathrm{a}} \pm 0.34$ & $78.42^{\mathrm{c}} \pm 0.25$ \\
Loin eye area (cm $\left.{ }^{2}\right)$ & $39.56^{\mathrm{c}} \pm 0.67$ & $43.70^{\mathrm{a}} \pm 0.79$ & $36.87^{\mathrm{d}} \pm 0.48$ & $43.20^{\mathrm{a}} \pm 0.80$ & $40.56^{\mathrm{b}} \pm 0.61$ \\
pH at 1h postmortem & $6.27^{\mathrm{bc}} \pm 0.02$ & $6.30^{\mathrm{ab}} \pm 0.02$ & $6.21^{\mathrm{c}} \pm 0.02$ & $6.25^{\mathrm{bc}} \pm 0.02$ & $6.34^{\mathrm{a}} \pm 0.02$ \\
pH at 24 h postmortem & $5.51^{\mathrm{c}} \pm 0.01$ & $5.63^{\mathrm{a}} \pm 0.01$ & $5.53^{\mathrm{bc}} \pm 0.01$ & $5.55^{\mathrm{b}} \pm 0.02$ & $5.55^{\mathrm{b}} \pm 0.01$ \\
Moisture (\%) & $74.65^{\mathrm{bc}} \pm 0.13$ & $75.27^{\mathrm{a}} \pm 0.09$ & $74.38^{\mathrm{c}} \pm 0.12$ & $74.96^{\mathrm{ab}} \pm 0.19$ & $73.53^{\mathrm{d}} \pm 0.11$ \\
Protein (\%) & $22.61^{\mathrm{b}} \pm 0.10$ & $22.59^{\mathrm{b}} \pm 0.08$ & $21.84^{\mathrm{c}} \pm 0.06$ & $22.90^{\mathrm{a}} \pm 0.13$ & $22.41^{\mathrm{b}} \pm 0.08$ \\
Fat (\%) & $1.70^{\mathrm{b}} \pm 0.16$ & $1.09^{\mathrm{c}} \pm 0.08$ & $2.76^{\mathrm{a}} \pm 0.14$ & $1.09^{\mathrm{c}} \pm 0.13$ & $2.82^{\mathrm{a}} \pm 0.11$ \\
Ash (\%) & $1.04 \pm 0.01$ & $1.05 \pm 0.02$ & $1.01 \pm 0.01$ & $1.06 \pm 0.01$ & $1.04 \pm 0.00$ \\
\hline
\end{tabular}

${ }^{\dagger}$ LY : Landrace $\times$ Yorkshire, LYD : Landrace $\times$ Yorkshire $\times$ Duroc.

${ }^{\text {ad }}$ : Values with different superscripts in the same row differ significantly $(p<0.05)$. 
higher in Duroc crossbreds than in the Yorkshire, Landrace, and Hampshire crossbreds, but protein percentage was the lowest in Duroc crossbreds. Fat content for LYD and Duroc pigs was significantly $(p<0.05)$ higher than that for other breeds. Present results were in agreement with reports that the meat from Durocs and Duroc sired pigs contained more intramuscular fat than from Yorkshires and Yorkshire sired pigs (Enfalt et al., 1997; Wood et al., 1996). Barton-Gade (1988) reported that intramuscular fat contents of 3.21, 1.58, 1.59, and $1.86 \%$ for Duroc, Landrace, Large White and Hampshire breed pigs, respectively. Sellier (1988) concluded that Duroc pigs generally showed a markedly higher intramuscular fat content than Large White or Landrace pigs (+2\% on average). McGloughlin et al. (1988) evaluated the Duroc breed as a terminal sire and reported that Duroc crosses had significantly less backfat but higher intramuscular fat content (2.9\%) than Irish Landrace $\times$ Large White crosses (2.0\%). There were no appreciable differences in percentage of ash content in the LD muscle from all breeds.

\section{Effect of breed on objective and subjective meat quality}

Table 2 compares objective and subjective meat quality between the breeds. LYD pigs were lower shear force values compared with that from other breeds and demonstrated the best water holding capacity among breeds $(\mathrm{p}<0.05)$. Jeremiah et al., (1999) reported that the meat from Landrace and Yorkshires had higher shear force values than the meat from Durocs. Also, Enfalt et al., (1997) reported that the meat from Duroc sired pigs was more tender than the meat from Yorkshire sired pigs. Concerning cooking loss and purge loss, the LD muscle from LYD and Duroc pigs was significantly lower compared with that from other breeds, respectively $(p<0.05)$. However, Lo et al. (1992) reported that there were no significant differences between Duroc and Landrace pigs for most of the objective measurements of loin muscle quality (i. e., cooking loss, shear value, and water-holding capacity). Also, drip loss was higher in meat from Duroc pigs in one report (Smith and Pearson, 1986) but subsequent studies failed to confirm this (McGloughlin et al., 1988; Martel et al., 1988).

In the measurement of objective meat color, hunter $L^{*}$ value was lower for LYD pigs when compared to that from other breeds $(\mathrm{p}<0.05)$. Hunter $a^{*}$ value was higher in LY pigs than in other breeds $(\mathrm{p}<0.05)$ and hunter $b^{*}$ value was the highest for Landrace pigs $(\mathrm{p}<0.05)$. Langlois and Minvielle (1989) found Hampshire and Duroc

Table 2. Mean and standard deviation for meat quality of Longissimus muscle from Landrace, Yorkshire, Duroc, LY and LYD crossbred pigs

\begin{tabular}{lrrrrr}
\hline Traits & \multicolumn{1}{c}{ Landrace } & \multicolumn{1}{c}{ Yorkshire } & \multicolumn{1}{c}{ Duroc } & \multicolumn{1}{c}{ LY } & LYD \\
\hline \hline Shear force (0.5in. $\left.{ }^{2} / \mathrm{kg}\right)$ & $4.19^{\mathrm{a}} \pm 0.68$ & $3.98^{\mathrm{ab}} \pm 0.12$ & $3.66^{\mathrm{ab}} \pm 0.12$ & $4.02^{\mathrm{ab}} \pm 0.18$ & $3.47^{\mathrm{b}} \pm 0.09$ \\
Water holding capacity (\%) & $53.64^{\mathrm{c}} \pm 0.41$ & $52.56^{\mathrm{c}} \pm 0.36$ & $58.33^{\mathrm{b}} \pm 0.44$ & $52.95^{\mathrm{c}} \pm 0.41$ & $61.66^{\mathrm{a}} \pm 0.30$ \\
Cooking loss (\%) & $37.01^{\mathrm{ab}} \pm 0.81$ & $36.86^{\mathrm{b}} \pm 0.31$ & $36.87^{\mathrm{b}} \pm 0.27$ & $38.11^{\mathrm{a}} \pm 0.35$ & $35.00^{\mathrm{c}} \pm 0.32$ \\
Purge loss (\%) & $4.31^{\mathrm{a}} \pm 0.34$ & $3.19^{\mathrm{b}} \pm 0.31$ & $1.37^{\mathrm{d}} \pm 0.17$ & $2.87^{\mathrm{b}} \pm 0.32$ & $2.10^{\mathrm{c}} \pm 0.12$ \\
Hunter L & $49.63^{\mathrm{a}} \pm 0.75$ & $47.79^{\mathrm{ab}} \pm 0.50$ & $46.23^{\mathrm{bc}} \pm 0.36$ & $48.56^{\mathrm{ab}} \pm 1.49$ & $44.72^{\mathrm{c}} \pm 0.28$ \\
Hunter a & $7.13^{\mathrm{ab}} \pm 0.30$ & $6.15^{\mathrm{ab}} \pm 0.28$ & $5.58^{\mathrm{b}} \pm 0.11$ & $7.33^{\mathrm{a}} \pm 0.60$ & $6.02^{\mathrm{b}} \pm 0.12$ \\
Hunter b & $5.39^{\mathrm{a}} \pm 0.26$ & $4.29^{\mathrm{bc}} \pm 0.20$ & $3.88^{\mathrm{c}} \pm 0.09$ & $4.96^{\mathrm{ab}} \pm 0.54$ & $4.35^{\mathrm{bc}} \pm 0.10$ \\
Juiciness* & $3.44^{\mathrm{b}} \pm 0.06$ & $3.49^{\mathrm{b}} \pm 0.06$ & $4.12^{\mathrm{a}} \pm 0.05$ & $3.58^{\mathrm{b}} \pm 0.09$ & $3.98^{\mathrm{a}} \pm 0.05$ \\
Tenderness & $3.63^{\mathrm{b}} \pm 0.08$ & $3.61^{\mathrm{b}} \pm 0.07$ & $4.17^{\mathrm{a}} \pm 0.08$ & $3.61^{\mathrm{b}} \pm 0.13$ & $4.15^{\mathrm{a}} \pm 0.07$ \\
Flavor & $4.06^{\mathrm{c}} \pm 0.05$ & $4.02^{\mathrm{c}} \pm 0.04$ & $4.31^{\mathrm{b}} \pm 0.04$ & $4.11^{\mathrm{c}} \pm 0.06$ & $4.48^{\mathrm{a}} \pm 0.04$ \\
\hline
\end{tabular}

For other abbreviations see Table 1.

a-d : Values with different superscripts in the same row differ significantly $(\mathrm{p}<0.05)$.

* Based on 6-point evaluation (Juiciness, $1=$ very dry, $6=$ very juicy; Tenderness, $1=$ very tough, $6=$ very tender; Flavor, 1 = very objectionable, 6 = very acceptable). 
breeds generally had a darker meat color than Yorkshire and Landrace breeds. In contradiction, Wood et al. (1996) reported the color of $M$. longissimus thoracis et lumborum from Duroc and Large White pigs was not significantly difference between breeds.

In the sensory properties, juiciness and tenderness scores were higher in Duroc and LYD pigs than in other breeds $(P<0.05)$. LYD pigs received the highest $(\mathrm{P}<0.05)$ flavor scores. These results could be anticipated because Duroc and LYD had much more fat than the other breeds. Present results are in agreement with reports that the meat from Durocs was perceived to be more juicy than the meat from Landrace and Yorkshires and had a more desirable flavor than the meat form Landrace and Yorkshires (Jeremiah et al., 1999). Also, Danish researchers found that the Duroc had higher levels of intramuscular fat than other breeds and also had associated positive effects on meat flavor, tenderness, and juiciness (BartonGade and Bejerholm, 1985; Bejerholm and BartonGade, 1986). Ellis et al. (1990) reported improvements in juiciness and overall acceptability associated with higher intramuscular fat content. However, Edwards et al. (1988) detected no significant breed effects for any eating quality trait, although the proportion of intramuscular fat in loin chops was greater for Duroc-than for British Large White-sired pig. Collectively, the current study showed that the meat from Duroc purebred and LYD crossbred pigs had improved meat quality (e.g. fat percentage, shear force, purge loss and sensory), however they had lower carcass pro-ductivity when compared to the other breeds. The further study on the establishment of cross-bred pigs produced from different terminal sire breeds are necessary to produce pork with high acceptance in meat quality as well as carcass yields.

\section{ACKNOWLEDGMENT}

The authors acknowledge the financial support of RDA grant for the current study.

\section{REFERENCES}

1. AOAC. 1990. Official methods of analysis. 15th ed. Association of Official Analytical Chemists. Washington, D. C.

2. APGS. 1995. Report of business for animal products grading. Animal products grading system, National Livestock Co-operatives Federation, Seoul, Korea.

3. Barton-Gade, P. A. 1988. The effect of breed on meat quality characteristics in pigs. In Proc 34th International Congress of Meat Science and Technology, Brisbane, Australia. pp. 568-570.

4. Barton-Gade, P. A. and Bejerholm, C. 1985. Eating quality of pork-What the Danes have found. Pig Farming 33:56.

5. Bejerholm, C. and Barton-Gade, P. A. 1986. Effect of intramuscular fat level on eating quality of pig meat. In: Proc. 32 ${ }^{\text {nd }}$ European Mtg. Meat Res. Workers. Ghent, Belgium. pp. 389-391.

6. Devol, D. L., McKeith, F. K., Bechtel, P. J., Novakofski, J., Shanks, R. D. and Carr, T. R. 1988. Variation in composition and palatability traits and relationships between muscle characteristics and palatability in a random sample of pork carcasses. J. Anim. Sci. 66:385-395.

7. Edwards, S. A., Wood, J. D., Moncrieff, C. B., Poter S. J. and Whitehouse, J. M. 1988. The effects of breed and diet on pig carcass quality. Anim. Prod. 46:503(Abstr.).

8. Ellis, M., Webb, A. J., Avery, P. J., Brown, I. and Smithard, R. 1990. Evidence for genetic variation in the eating quality of pork. In: Proc $4^{\text {th }}$ World Congr. Genet. Appl. Livest. Prod. Edinburgh, UK. XV:553.

9. Enfalt, A. C., Lundstrom, K., Karlsson, A. and Hansson, I. 1997. The frequency of the RN-allele in Swedish Hampshires and comparison of glycolytic potential, carcass composition, and technological meat quality among Swedish Hampshire, Landrace, and Yorkshire pigs. J. Anim. Sci. 75:2924-2935.

10. Essen-Gustavsson, B., Karlsson, A., Lundstrom, K. and Enfalt, A. C. 1994. Intramuscular fat and muscle fibre lipid contents in halothane-gene-free pigs fed high or low protein diets and its relation to meat quality. Meat Sci. 38:269-277. 
11. Essen-Gustavsson, B. and Fjelkner-Modig, S. 1985. Skeletal muscle characteristics in different breeds of pigs in relation to sensory properties of meat. Meat Sci. 13(1):33-47.

12. Goodwin, R. N. 1995. Genetic parameters of pork quality traits. The Sciences and Engineering, Dissertation. Abstr. International. 57(4):3733-3740 (Section-B).

13. Grau, R. and Hamm, R. 1952. Eine einfache methode zür bestimmung der wasserbindung in fleisch. Fleischwirtsch. 4:295-297.

14. Grau, R. and Hamm, R. 1956. Die bestimmung der wasserbindung des fleisches mettels der preßmethode. Fleischwirtsch. 8:733-734.

15. Jeremiah, L. E., Gibson, J. P., Gibson, L. L., Ball, R. O., Aker, C. and Fortin, A. 1999. The influence of breed, gender, and PSS (Halothane) genotype on meat quality, cooking loss, and palatability of pork. Food Res. International. 32:59-71.

16. Kim, J. H., Park, B. Y., Yoo, Y. M., Cho, S. H., Kim, Y. K., Lee, J. M., Yun, H. J. and Kim, K. N. 2002. Characterstics of carcass and meat yields of fattening pigs by production step. J. Anim. Sci. \& Technol. (Kor.). 44:793-800.

17. Langlois, A. and Minvielle, F. 1989. Comparisons of three-way and backcross swine: $\Pi$. Wholesale cuts and meat quality. J. Anim. Sci. 67:2025-2032.

18. Lo, L. L., McLaren, D. G., McKeith, F. K., Fernando R. L. and Novakofski, J. 1992. Genetic analyses of growth, real-time ultrasound, carcass, and pork quality traits in duroc and landrace pigs: I. Breed effects. J. Anim. Sci. 70:2373-2386.

19. Martel, J., Minvielle, F. and Poste, L. M. 1988. Effects of crossbreeding and sex on carcass composition, cooking properties and sensory characteristics of pork. J. Anim. Sci. 66:41-46.

20. McGloughlin, P., Allen, P., Tarrant, P. V., Joseph, R. L., Lynch, P. B. and Hanrahan, T. J. 1988. Growth and carcass quality of crossbred pigs sired by Duroc, Landrace and Large White boars. Livest. Prod. Sci. 18:275-288.

21. Monin, G. 1983. Influence des conditions de production et d'abattage sur les qualities technologiques et organoleptiques des viands de porc. J. Rech. Porcine Fr. 15:151-176.
22. Park, B. Y., Yoo, Y. M., Kim, J. H., Cho, S. H., Kim, S. T., Lee, J. M. and Kim, Y. K. 1999. Effect of intramuscular fat contents on meat quality of pork loins. Kor. J. Anim. Sci. 41:59-64.

23. SAS. 1998. Applied statistics and the SAS programming language. SAS Institute INC, Cary, NC, USA.

24. Sellier, P. 1988. Meat quality in pig breeding and in crossbreeding. In: Proc. Int. Mtg. On Pig Carcass and Meat Quality Univ. di Bologna, Reggio Emilia, Italy. pp. 145-164.

25. Sellier, P. and Monin, G. 1994. Genetics of pig meat quality: a review. J. Muscle Foods, 5:187-219.

26. Sigvardsson, J. 1983. Korningsförsök med Duroc som slaktsvinsfader. Konsulentavdelningens Rapporter. 44:1-9.

27. Smith, W. C. and Pearson, G. 1986. Comparative voluntary feed intakes, growth performance, carcass composition, and meat quality of Large White, Landrace, and Duroc pigs. New Zealand of Journal of Experimental Agriculture. 3:43-50.

28. Steindel, B. and Kaczmarek, W. 1980. Comparison of meat quality of Belgium Landrace, Polish Large White, and Polish Landrace purebred and Belgium Landrace $\times$ Polish Landrace crossbred swine. RocznikiNaukawe Zrotechniki. 7(1):123-130.

29. Wilken, T. M., Lo, L. L., McLaren, D. G., Fernando, R. L. and Dziuk, P. J. 1992. An embryo transfer study of reciprocal cross differences in growth and carcass traits of Duroc and Landrace pigs. J. Anim. Sci. 70:2349-2358.

30. Wilson, E. R. and Johnson, R. K. 1981. Comparison of three-breed and backcross swine for litter productivity and post weaning performance. J. Anim. Sci. 52:18-25.

31. Wood, J. D., Richardson, R. I., Nute, G. R., Fisher, A. V., Campo, M. M., Kasapidou, E., Sheard, P. R. and Enser, M. 2003. Effects of fatty acids on meat quality: a review. Meat Sci. 66:21-32.

32. Wood, J. D., Brown, S. N., Nute, G. R., Whittington, F. M., Perry, A. M., Johnson, S. P. and Enser, M. 1996. Effects of breed, feed level and conditioning time on the tenderness of pork. Meat Sci. 44(1/2): 105-112.

(접수일자 : 2005. 7. 22. / 채택일자 : 2005. 12. 20.) 